\title{
The burning issue of dung in archaeobotanical samples: a case-study integrating macro-botanical remains, dung spherulites, and phytoliths to assess sample origin and fuel use at Tell Zeidan, Syria
}

\author{
Alexia Smith ${ }^{1} \cdot$ Lucas Proctor $^{1} \cdot$ Thomas C. Hart $^{2} \cdot$ Gil J. Stein ${ }^{3}$ \\ Received: 8 October 2017 / Accepted: 25 July 2018 / Published online: 14 September 2018 \\ (c) The Author(s) 2018
}

\begin{abstract}
Since Naomi Miller's first discussion of dung fuel within macro-botanical samples from Malyan, Iran, considerations of dung fuel across Southwest Asia have become commonplace, yet archaeobotanists remain divided on: (1) the extent to which dung fuel contributed to archaeobotanical assemblages relative to remnants of repeated crop processing and household activities; and (2) the plant-based, middle-range theories that should be used to infer the presence of dung within macro-botanical assemblages. Here we present a case-study integrating a simple, well-established geo-archaeological approach to assess the presence and relative abundance of dung spherulites within paired sediment and flotation samples from Ubaid period Tell Zeidan, Syria (5300-5100 вс). Spherulite data generated from "sediment smears" are integrated with macro-botanical and phytolith data to assess elevated concentrations of dung within samples. Our analyses demonstrate that plant-based depositional processes across a site are complex, reflecting the rich nature of plant use in antiquity. By using a multi-proxy approach, it is possible to differentiate between predominantly fuel-based deposits and those resulting from predominantly crop-processing processes with greater resolution. This study documents the use of wood fuels in hearths and dung fuel within pyrotechnic features and an oven during the Ubaid period, thereby contributing to discussions of fuel selection and the Secondary Products Revolution. When spherulites are preserved within sediment in abundance, they are also present in floated material, so it is possible to use this approach to consider the presence of dung within archived macro-botanical samples and resolve decade-old debates.
\end{abstract}

Keywords Archaeobotany · Geoarchaeology $\cdot$ Dung spherulites $\cdot$ Phytoliths $\cdot$ Fuel use $\cdot$ Ubaid $\cdot$ Secondary products revolution

Communicated by A. Farahani.

Electronic supplementary material The online version of this article (https://doi.org/10.1007/s00334-018-0692-9) contains supplementary material, which is available to authorized users.

Alexia Smith

alexia.smith@uconn.edu

1 Department of Anthropology, University of Connecticut, Beach Hall, Unit 1176, 354 Mansfield Road, Storrs, CT 06269-1176, USA

2 Department of Anthropology, Franklin and Marshall College, P.O. Box 3003, Lancaster, PA 17604, USA

3 The Oriental Institute, 1155 East 58th Street, Chicago, IL 60637, USA

\section{Introduction}

Following the introduction of flotation as a tool for recovering charred plant remains from archaeological sediments in the 1960s and 1970s (Jarman et al. 1972), the range of questions posed by archaeobotanists examining macro-remains across Southwest Asia has steadily broadened from studies of important economic taxa and the nature and timing of the origins of agriculture to include examinations of crop processing stages and agronomic methods used by farmers; landscape use; the identification of activity areas across sites; social organization of labor; and the dynamic relationships between subsistence strategies, environmental change, and socio-economic organization (e.g. Hillman 1975; Hillman et al. 1989; Bogaard et al. 1999; Jones et al. 2010; Stevens 2003; Miller 2010; Graham and Smith 2013; Riehl 2009). In the early 1980s, Naomi Miller's work at Malyan, 
Iran, highlighted the potential for remnants of dung fuel to be preserved archaeologically (Miller 1982, 1984a, b, 1985; Miller and Smart 1984) and, since then, considerations of dung fuel within macro-botanical assemblages across Southwest Asia have become commonplace (Spengler 2018). The archaeobotanical community as a whole generally accepts that charred dung fuel is preserved archaeologically across Southwest Asia, yet researchers remain divided on: (1) the extent to which dung fuel contributes to archaeobotanical assemblages relative to remnants of repeated crop processing and household activities; and (2) the approaches that should be used to infer the presence of dung within macro-botanical assemblages. Gaining consensus on this issue is important for a variety of reasons. First, the very nature of the questions that can be reliably addressed using archaeobotanical remains is firmly linked to our understanding of sample origin and depositional processes. Furthermore, in recent years, anthracologists have highlighted the wide range of social, cultural, functional and economic factors underpinning fuel selection and use that can be addressed through studies of wood fuels (Picornell Gelabert et al. 2011; ThéryParisot et al. 2010). Through these studies, they stress the important role that fuel management serves within a society, equating it with the importance of subsistence strategies. Macro-botanical studies hold enormous potential to contribute to these discussions by providing information on both wood and dung fuels, where present (Smith et al. 2015a). We assert that once the presence of dung within archaeobotanical samples is more securely supported, it will be easier to address the extent to which dung contributes to archaeobotanical assemblages, thereby placing the rich interpretive power of archaeobotanical analyses on a firmer footing. Before this can be done, however, archaeobotanists must gain consensus on how to definitively and consistently identify rather than infer dung within their samples.

Intact sheep or goat pellets or heterogeneous fragments of cow dung are sometimes recovered in flotation samples, providing direct evidence of the presence of dung, but such remnants are not always indicative of fuel (Charles 1998). The very process of burning fuel cakes often results in assemblages of isolated seeds within a matrix of ash that can be difficult to interpret (Wallace and Charles 2013; Anderson and Ertug-Yaras 1998; Schepers and van Haaster 2015). To date, discussions of the presence of dung within flotation samples have relied almost exclusively upon middle-range theoretical models that interpret macro-botanical assemblages alongside archaeological contextual information yet, depending upon which models are used, similar assemblages have been used to argue both for the widespread presence or complete absence of dung, leading to what Fuller et al. (2014, p 175) aptly refer to as "the vexed issue of the role of dung burning in the creation of Old World seed assemblages." Hillman (1981, p 125) convincingly argued that careful consideration of the composition of an archaeobotanical assemblage can provide information on the nature of the archaeological context and the ways in which plants were deposited, but this approach breaks down when similar seed assemblages are confidently interpreted by different researchers as having vastly dissimilar origins. In such instances, while the models are admittedly sophisticated, additional information is required to bridge the divide and gain more objective insights into sample origin.

Numerous well-established geo-archaeological tools exist for positively identifying dung (including dung spherulite, chemical, genetic, and micro-morphological analyses), yet, to date, these approaches have rarely been integrated with macro-botanical studies. Many geo-archaeologists readily accept the rich interpretive power of archaeobotanical studies of burned dung fuel, but reject the idea that dung can be positively "identified" based on macro-remains alone (e.g. Shahack-Gross 2011), instead preferring a multi-proxy approach that incorporates more objective markers of dung. Interestingly, the same critique has not been applied as forcefully to phytolith data, despite the fact that plants recovered in phytolith form also represent numerous depositional processes that extend well beyond fuel use. As work integrating phytolith studies with geo-archaeological approaches has shown, however, information gleaned from plant remains can be greatly increased when using even the most basic of geo-archaeological techniques as part of a multi-proxy approach (e.g. Albert et al. 2008; Lancelotti and Madella 2012; Madella 2003; Portillo et al. 2014; Shahack-Gross 2011).

In this paper we explore the utility of integrating dung spherulite analyses with traditional archaeobotanical analyses of macro-remains in order to help better assess the potential presence of dung within our samples. We begin with an overview of the ways that dung fuel has been discussed within the archaeobotanical literature and then briefly summarize the range of geo-archaeological studies that have been used to positively identify dung within sediments. The full range of techniques may prove useful in the future, but here we focus on spherulites because their presence has repeatedly been reported in archaeological sediments across Southwest Asia (e.g., Matthews 2010), and they are relatively easy to observe through simple "sediment smears," that could be prepared and examined in most archaeobotany labs with minimal effort. We then present a case-study examining the presence and relative abundance of dung spherulites within 31 paired sediment and flotation samples excavated from a range of Ubaid period contexts at Tell Zeidan, Syria (Fig. 1). Paired samples were chosen to: (1) allow for the baseline of spherulite abundance within sediment samples from Zeidan to be documented using a well-established method; (2) assess whether spherulites can be recovered through flotation using these same methods; and (3) if so, determine whether relative abundances match those 


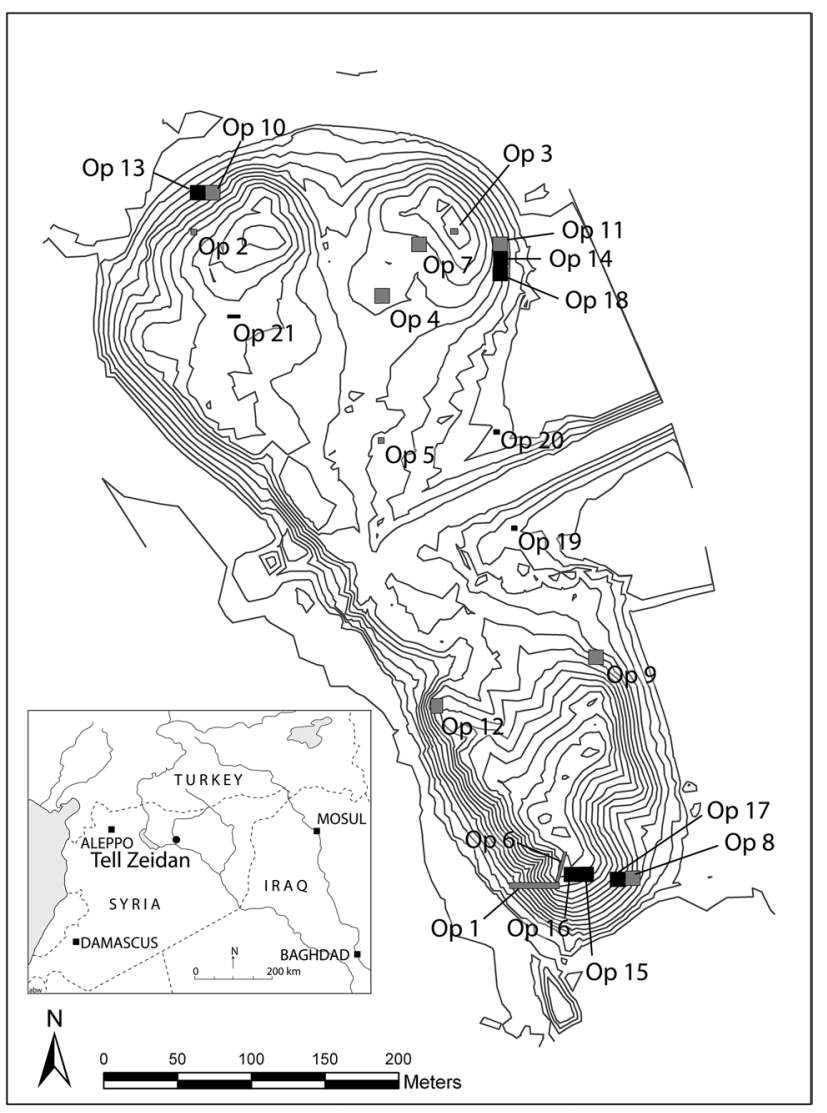

Fig. 1 Plan of Tell Zeidan showing location of Operations excavated between 2008 and 2010 (courtesy of G. J. Stein and the Tell Zeidan Project). Inset map shows location of Tell Zeidan (base map created by Al B. Wesolowsky)

of associated sediments. It has generally been assumed that any spherulites present within sediment would be lost through the process of flotation, but this assertion has never been tested. While examining spherulites in sediments remains the best approach, if spherulites can be observed in flotation samples in a meaningful way, this technique would allow information to be generated from curated flotation collections that do not have associated sediment samples and could potentially resolve debates that span decades. Given that a number of studies focused on the identification of dung have successfully integrated spherulite and phytolith studies, we also include preliminary phytolith data from Tell Zeidan alongside spherulite and macro-botanical data. A detailed study integrating phytolith and macro-botanical data from Tell Zeidan is ongoing, so discussions of phytolith assemblages here remain brief. We conclude with a critical discussion of the benefits and constraints of integrating spherulites and macro-botanical analyses.

\section{Approaches to inferring dung within archaeobotanical samples}

In the 1980s, Miller and Smart (1984, p 20) reasoned that dung could be present within archaeobotanical samples at sites where four conditions were met: (1) wood fuel was scarce; (2) dung-producing animals were present; (3) charred plant assemblages contain dung or seeds that could have been eaten by a dung-producing animal; and (4) the archaeological context of the sample suggested fuel use or disposal. Ethnographic observations of dung fuel production and use around the world have shown that dung cakes are routinely made by mixing herbivore dung with crop processing debris (Fig. 2). In Southwest Asia, dung from sheep, goats and cows is commonly used (Anderson and Ertug-Yaras 1998) and when burned, seeds and plant parts within the dung, along with other plant material used to manufacture the dung cakes, become mixed with kindling or any other crop processing or food debris deposited in the fire and potentially preserved (e.g. Bottema 1984; Reddy 1998; Hastorf and Wright 1998; Miller 1984b; Charles 1998; Anderson and Ertug-Yaras 1998; Lancelotti and Madella 2012). Once the remnants of the burned fuels are disposed of, often in middens or pits, further mixing can occur with other debris creating long-term accumulations of repeated household practices (McCorriston and Weisberg 2002; Shillito and Matthews 2013; Fuller et al. 2014). Under mundane preservation conditions (rather than catastrophic), separating remnants of repeated crop processing or household activities from dung remains and disentangling the relative contribution of each process within samples with mixed depositional histories is, therefore, no simple matter and requires careful consideration (Fuller et al. 2014; Deckers 2011). Recognizing these complexities, Charles (1998, p 113) argued that ecological information on weeds within samples should be considered alongside information gleaned from ethnographic observations of crop processing by Jones (1984) and Hillman (1984) in order to strengthen inferences of charred dung within archaeobotanical samples.

Currently, when the presence of dung is suspected or assumed across a site, some researchers use ratios of various plant groupings recovered through flotation to infer the relative contribution of wood to dung fuel. The results of such studies have then been used to examine questions of landscape use and deforestation (e.g. Miller 1990), assuming that wood fuels will be selected over dung where wood is readily available (but see Deckers 2011). Studies weighing the relative importance of dung and wood fuels have tended to consider remains at the site or phase (rather than sample) level, losing resolution of plant use that may be represented on a smaller scale. Frequently, differences exist on 
which specific plant groupings should be chosen, or whether remains should be quantified by counts, weights, or a mix of both, resulting in divergent approaches between scholars and sites. Generally, amounts of wood are compared to amounts of weedy or wild seeds, but some scholars also include fruits (e.g. Miller and Marston 2012; Miller et al. 2009; Fall et al. 2015; Deckers 2011). Replicating the application of ratios between studies can prove difficult in instances where the boundaries of each plant grouping or the units of measure are not described in detail (Smith et al. 2015a). Eschewing site-wide ratios for a more contextual approach, some scholars consider the physical properties of seeds and the ecology of weed assemblages to infer whether individual samples represent pure caches of crop-processing debris or mixed assemblages that may contain dung, or adopt a combined approach integrating ratios with an ecological and crop-processing perspective (e.g. Charles 1998; Smith 2012; Smith et al. 2015a, b; Charles and Bogaard 2001).

Debate began in the 1990s when Miller (1996, 1997b) challenged Helbaek's (1969) and Hillman et al.'s (1989) interpretations of plant remains from Neolithic Ali Kosh, Iran and Epipalaeolithic Abu Hureyra, Syria, respectively. She argued that both assemblages likely represented remains of dung fuel rather than food, thereby providing insight into foddering and pasturing practices rather than the range of plants gathered for human consumption. With reference to samples from cultural fill where catastrophic fires are absent, Miller (1996, p 526, emphasis in original) reasoned that given that fuel is "routinely and necessarily put in fires... probability alone would suggest that most charred remains come from fuel." While not discounting remnants of food in burned storage or cooking contexts, Miller stressed the need for careful consideration of archaeological context when interpreting remains (Miller 1991, p 527, 1996), and suggested that in order to distinguish between fuel and food, data listing quantities of wood charcoal per sample needed to be gathered, considered, and published. Hillman et al. (1997) acknowledged that dung was likely an important source of plant remains on Neolithic and post-Neolithic sites, but countered Miller's assertion that gazelle dung was used as a fuel during the Epipalaeolithic at Abu Hureyra, maintaining that the bulk of the seeds represented deposits of food.

As this debate highlights, the ability to accurately assess sample origin is of fundamental importance to archaeobotany, given that the research questions addressed are largely shaped by beliefs about processes of deposition that resulted

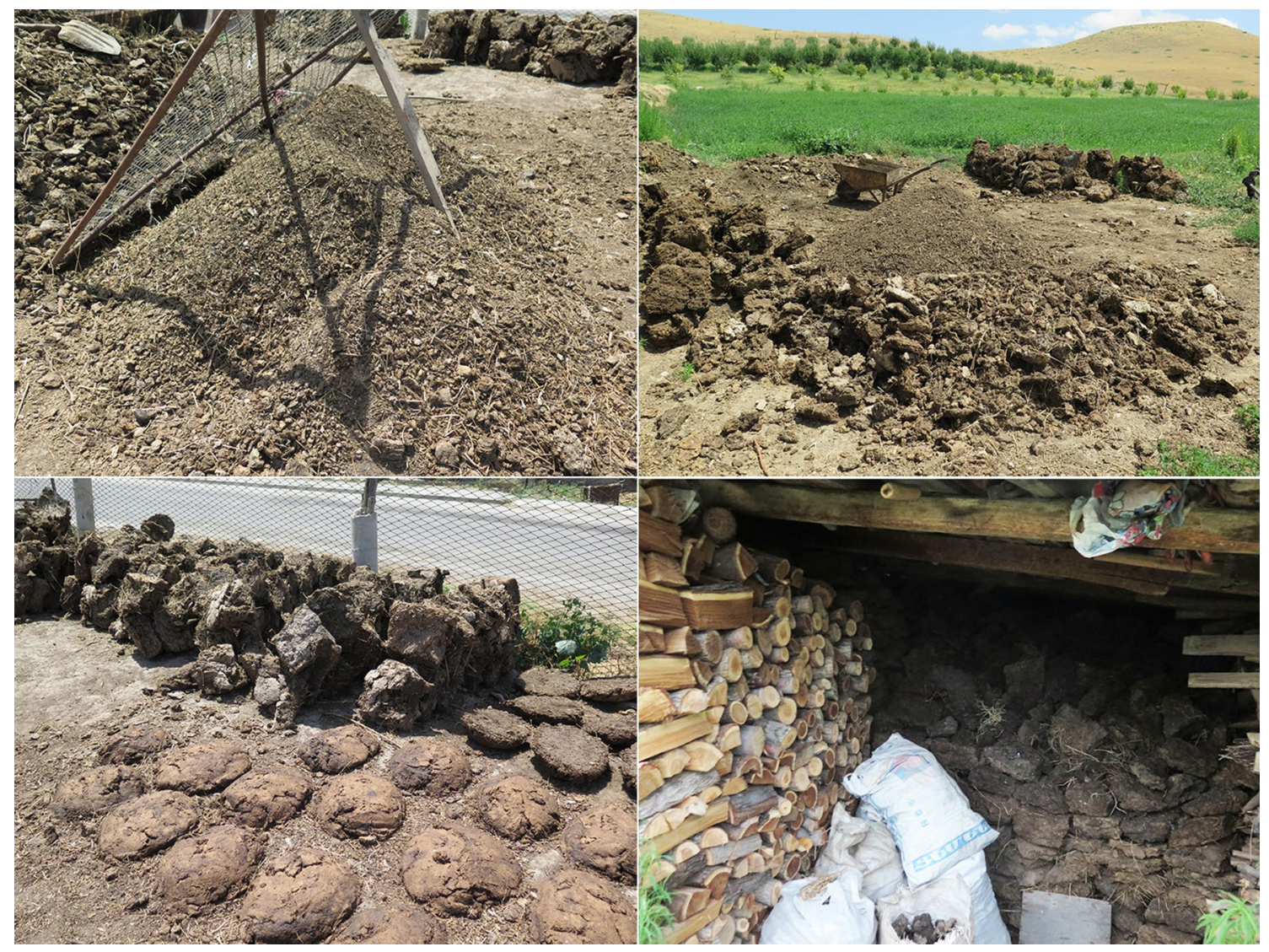

Fig. 2 Photographs of modern dung cake preparation and storage in several villages across southern Armenia. Cereal chaff is visible in many of the dung cakes 
in any given assemblage. When remnants of burned dung are present in flotation samples, the plant remains provide insights into pasturing, foddering and seasonal animal management practices from early agricultural to fully-fledged state level societies, together with the socioeconomic choices underpinning fuel selection, use and landscape use, and also contribute to our understanding of the Secondary Products Revolution and the earliest use of dung fuel (e.g. Miller 1990, 1997a; Schepers and van Haaster 2015; Valamoti 2007; Panadès i Blas et al. 2017; Deckers 2011; Elliott et al. 2015). In contrast, when plants represent the remains of food preparation, storage, or crop processing, questions centre on the agronomic choices farmers made to grow crops, or the social organization of crop processing and food preparation (e.g. Graham and Smith 2013; Smith 2012; Fuller et al. 2014; Stevens 2003; Charles and Hald 2003; Riehl 1999; Charles and Bogaard 2001). Both depositional pathways are important contributors to plant assemblages, but the prevalence of each is likely to vary both between and within sites and phases reflecting the rich history of plant use and activities that we aim to reconstruct. The adoption of geo-archaeological and chemical tools for identifying dung in association with macro-botanical analyses, while not a panacea, has the potential to provide an enriched tool set to better assess depositional pathways and enhance the resolution of insights into plant use in antiquity.

\section{Archaeological approaches to identifying dung}

Over the past few decades, the range of approaches used to identify dung archaeologically has broadened considerably, forming a robust and coherent field of research addressing a wide array of research questions (for useful summaries see Marinova et al. 2013; Friesem 2016; Shahack-Gross 2011). Methods used to identify dung on archaeological sites include phosphate, genetic, isotopic or contextual micro-morphological analyses along with studies of predatory mites or intestinal parasites (Jones et al. 2015; Schelvis 1992), and lipid biomarkers such as $5 \beta$-stanols (Evershed et al. 1997; Bull et al. 1999, 2005; Simpson et al. 1998). Since each approach has relative strengths and weaknesses in isolation, multi-proxy approaches are often adopted. Once identified, the presence of animal dung has been used to document a range of behaviours, including the following: animal penning; pasturing, foddering and seasonal herd management strategies; mundane and ritual selection of construction materials for floors, ovens, and walls; fuel use; and application of organic fertilizer (when applied fresh or dried) or inorganic fertilizer (when applied in ash form after burning) within gardens or agricultural fields (Berna 2017; Gur-Arieh et al. 2013; Portillo et al. 2014, 2017; Albert et al. 2008; Miller and Gleason 1994; Schepers and van Haaster 2015; Valamoti 2007; Panadès i Blas et al. 2017; Deckers
2011; Elliott et al. 2015; Miller 1990; Matthews 2010). Within macro-botanical studies, the presence of inferred dung remains has most generally been used to discuss fuel selection and landscape use, although the potential to discuss penned areas and dung within building materials remains.

Given that this paper focuses on integrating spherulite analyses with macro-botanical data, factors affecting the formation and preservation of spherulites are presented below to provide useful background information and an entry-point into the growing body of literature on spherulites. This discussion is followed by a summary of ethno-archaeological studies that include phytoliths and other plant-based approaches related to dung and fuel use.

\section{Dung spherulite analyses}

Dung spherulites are small radially crystalized calcium carbonate spherical masses that vary between 5 and $15 \mu \mathrm{m}$ in diameter, with some reaching up to $25 \mu \mathrm{m}$ (Canti 1997, 1998, 1999; Morse and Donnay 1932, 1936; Brochier 1983). They are readily visible under cross-polarized light (XPL), exhibiting a clear extinction cross surrounded by bands of low-order white, first order red and second order blue. Canti (1998) provides a detailed description of the visual characteristics of spherulites (Fig. 3).

Spherulites are commonly produced in the intestines of adult ruminant herbivores such as sheep, goat, cow and deer (Canti 1999). Rates of formation tend to be high in domestic ruminants, low in omnivores such as pig, dog, and humans, and rare to absent in both caecal digesters, such as horse and rabbit, and carnivores (Canti 1999, p 254). Their production has been observed in a range of wild animals, including ibex, pigeon, rat and gazelle (Goren 1999), as well as chamois and wild boar (Brochier et al. 1992). Within species that produce spherulites, production can vary based on age, sex, individual calcium requirements (which tend to be higher for young animals and lactating females) and the presence of any calcium deficiency (Canti 1999). Additionally, spherulites readily dissolve under acidic conditions and, consequently, tend to be produced in very small quantities (if at all) by animals grazing on land with a soil $\mathrm{pH}$ of roughly 6.0 or less (Canti 1999). We were unable, for example, to observe any spherulites in cow and sheep dung from animals that had grazed on farms in Connecticut, where soil $\mathrm{pH}$ is approximately 6.0. Once produced and deposited, spherulites are less likely to be preserved in acidic sediments or sediments with high water flow-through (Gur-Arieh et al. 2014; Canti 1997). For this reason, very careful attention should be paid to site formation processes and laboratory methods used to extract or observe spherulites in archaeological sediments. Acidic chemicals should be avoided at all costs in any attempt to recover spherulites. Given that concentrations of ash are naturally alkaline, the preservation 
potential of any spherulites within undisturbed features with a pyric history is likely to be enhanced.

Spherulites have a melting point of roughly $800{ }^{\circ} \mathrm{C}$ and readily survive the charring process. While dung fires can reach $800{ }^{\circ} \mathrm{C}$ for a short period in the early stages of the fire when other materials such as wood are used as kindling, temperatures are not uniform throughout the fire and generally decrease to $500-600{ }^{\circ} \mathrm{C}$ for a while before dropping to around $400{ }^{\circ} \mathrm{C}$ for the bulk of the cooking time (Portillo et al. 2017). Around $300{ }^{\circ} \mathrm{C}$, the outer organic coating of spherulites tends to be removed from the inner mineral sphere, but this does not affect their ability to be identified under XPL (Figs. 2, 7 and 8 in Canti 1997). In fact, since the colour of spherulites can change with increasing temperatures, they may be used to infer maximum temperatures reached within a fire (Canti and Nicosia 2018).

Despite the various factors that affect production and preservation of spherulites, it is clear that when they are present within dung, they are able to survive a wide range of burning environments, and can be preserved archaeologically, representing a wide range of behaviours. It is important to stress, however, that given that spherulites do not form or are not preserved under acidic conditions, absence of evidence does not always equate with evidence of absence where these conditions prevail. Adopting a multi-proxy approach integrating other tools to identify dung serves as a way to explore sample origin further.

\section{Plant-based, multi-proxy approaches to observing dung fuel}

Over the past decade, a number of ethno-archaeological experiments have been conducted to better inform observations of dung and/or fuel archaeologically and some of these have included studies of phytoliths and ash-pseudomorphs. This research is relevant here because studies of phytoliths, ash-pseudomorphs and macro-botanical remains are highly complementary given their different preservation processes (Bates et al. 2017). Where macro-remains tend to include a wide range of taxa representing many different families, certain cereal chaff parts do not preserve well given that they readily turn to ash upon charring (Boardman and Jones 1990); conversely, phytoliths tend to be produced in abundance by a narrower range of families, but a wider range of plant parts are preserved. Given that phytoliths are abundant within grasses, by integrating phytolith and macro-botanical studies it is possible to examine a fuller range of chaff parts alongside associated weed data. In general, within macro-botanical studies, large amounts of culms or early stage processing debris are rarely observed and are often assumed to have been deposited off-site where harvesting, threshing or early-stage winnowing are thought to have taken place. When these plant parts are observed through phytolith studies, possibilities for their presence can be considered, including matting, fodder or admixtures within dung. Based on an ethnographic study of hearths within a single recently abandoned Baluchi camp in Pakistan, Madella (2003) was able to use phytoliths to differentiate between: (1) cooking hearths fueled by wood and scrub fuel, possibly supplemented with camel dung cakes that were dominated by inflorescence heads and dicotyledonous plant types; and (2) hearths fuelled by goat dung used to produce smoke that were dominated by grass stems and leaf phytoliths. In a similar ethno-archaeological study examining different fuel use in three domestic hearths in India, Lancelotti et al. (2017) combined phytolith and geochemical
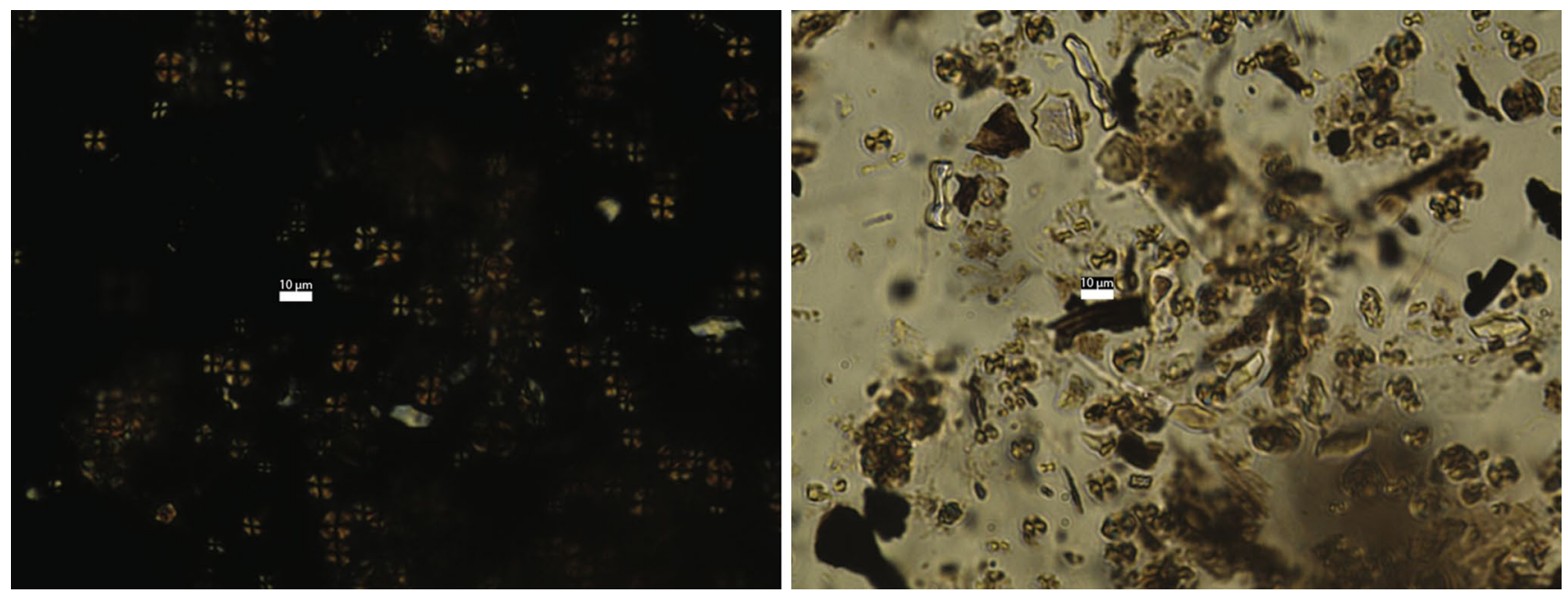

Fig. 3 Photograph of spherulites at $400 \times$ within modern comparative sheep/goat dung from Armenia charred at $600{ }^{\circ} \mathrm{C}$ for $2 \mathrm{~h}$. Images to the left show cross-polarized light; views to the rights display polarizer at 45 degrees (scale bars $=10 \mu \mathrm{m}$ ) 
analyses to help strengthen models for interpreting archaeological data. Employing chemical extraction methods similar to those devised to concentrate phytoliths, Gur-Arieh et al. (2013, 2014) examined modern fuel use in Uzbekistan and Bronze and Iron Age cooking installations in Israel, where differential ratios of ash pseudomorphs from wood ash to dung spherulites served as a good indicator of dominant fuel type indicating that both wood and dung can be used within the same feature. In a similar study examining phytoliths, spherulites and ash pseudomorphs within modern dung, wood and mixed fuels in Syria and Tunisia, Portillo et al. $(2014,2017)$ were also able to infer fuel choice and domestic activities from archaeological samples. Braadbaart et al. (2012) were also able to use concentrations of ashpseudomorphs and high concentrations of phytoliths to distinguish between wood and dung fuels respectively. Future studies adopting a similar ethno-archaeological approach to examining macro-botanical remains hold much potential for further deepening interpretations of archaeological remains.

\section{Tell Zeidan}

Tell Zeidan is a long triple mound spanning 12.5 ha that lies close to Raqqa at the confluence of the Balikh and Euphrates rivers (Fig. 1). Excavations led by the University of Chicago and the Raqqa Museum between 2008 and 2010 exposed a continuous occupational sequence spanning the Halaf through the Late Chalcolithic 2 (ca. 5800-3850 вс). Tell Zeidan is the largest Ubaid period site in Northern Mesopotamia, rivalling many of the large Ubaid settlements in Southern Mesopotamia. Readily accessible Ubaid architectural remains, radiocarbon dated to roughly $5300-4500 \mathrm{cal}$ $\mathrm{BC}$, span the entire site, providing an excellent opportunity to document the social organization of the settlement and examine the process of urbanization in Northern Mesopotamia during the Ubaid 3-4 period (Stein 2009, 2010, 2011). Numerous trenches exposed public buildings, private houses containing prestige goods, and specialized craft areas (Stein 2010). Within Operation 8 (Fig. 1), ten pyrotechnic features measuring roughly $1-1.5 \mathrm{~m} \times 1 \mathrm{~m}$ were exposed, resembling kilns found at other sites in the region (Stein 2010). No kiln wasters were found in Operation 8 , but the density of the features, combined with the lack of domestic architecture in the area, suggests intensive, specialized craft production. Excavations in Operations 11 and 14 (Fig. 1) revealed a large Ubaid domestic architectural complex spanning $300 \mathrm{~m}^{2}$ that contained multiple hearths, pits, and prestige goods (Stein 2010). These structures were built during the earliest Ubaid occupation at Tell Zeidan, representing two phases dating between 5300 and 5100 вс.

Prior macro-botanical analyses of 17 samples from Operation 8, and 30 samples from Operations 11 and 14 indicate a heavy reliance upon glume wheats at Tell Zeidan
(Smith et al. 2015b). Crops include barley (Hordeum vulgare ssp. distichum), emmer wheat (Triticum dicoccum), free-threshing wheat (T. durum/aestivum), lentil (Lens culinaris), bitter vetch (Vicia ervilia), pea (cf. Pisum sp.) and flax (Linum usitatissimum). No fruits were recovered and nut fragments were rarely encountered. Grains tended to be poorly preserved, but large concentrations of glume base fragments were common and were interpreted as the remnants of repeated and habitual on-site emmer spikelet processing (Smith et al. 2015b), mirroring the pattern evident at Ubaid period Kenan Tepe in southeastern Anatolia where a catastrophic fire preserved the process of dehusking grains at the household level in situ (Graham and Smith 2012, 2013). This preliminary study of macro-botanical remains observed mixed use of dung and wood fuels, with wood being abundant in many of the samples (Tables 1, 2; Smith et al. 2015b). No sheep or goat pellets were recovered.

Prior micro-botanical analyses generated phytolith data from 5 samples from Operation 8 and 16 samples from Operations 11 and 14 yielding a range of grassy inflorescence, leaf stem, Cyperaceae and woody/herbaceous types (Table 2; Hart 2014). Preliminary multi-variate analyses of the data indicate a distinct separation between the remains from the pyrotechnic features and the domestic areas. Assemblages from both areas are dominated by grassy leaf/ stem types, but samples from the domestic area tended to contain higher proportions of wild grass and cereal inflorescence types that are associated with late-stage crop processing. Blocks and tracheids representing woody tissues were present in both areas in very small proportions contrasting with the macro-botanical data. The implications of these findings are discussed below alongside the spherulite data.

\section{Materials and methods}

Spherulite abundance was examined within 31 paired sediment and flotation samples collected at Tell Zeidan from pyrotechnic features, hearths, ovens, pits and floors where fuel use or deposition of fuel remnants might be expected, as well as burials and bins, where an association with fuel use or disposal is less likely (Table 1). These data were considered alongside existing macro- and micro-botanical data. During excavation, approximately 101 of bulk sediment was collected from each archaeological context using a clean scoop. This bulk sediment was placed in a large clean mesh bag and brought to the dig house for bucket flotation using clean tap water. Prior to flotation, roughly $50 \mathrm{~g}$ of sediment was collected from each mesh bag and placed into a sterile plastic bag to serve as a paired sub-sample for phytolith and spherulite studies. The volume of the remaining bulk sediment was measured in litres and the light fraction was retrieved via bucket flotation in a muslin cloth with a mesh 
size of roughly $250 \mu \mathrm{m}$. The recovered light fractions were dried in the shade and brought to the University of Connecticut Archaeobotany Laboratory for analysis. The volume and mass of each sample was recorded in $\mathrm{ml}$ and $\mathrm{g}$ respectively, and all light fractions were separated using clean 4, 2 and $1 \mathrm{~mm}$ sieves prior to sorting. All material $>1 \mathrm{~mm}$ was sorted in full and the taxa present identified. The $<1 \mathrm{~mm}$ fraction was scanned and identifiable plant parts were removed and recorded (Smith et al. 2015b).

Phytoliths were extracted using the methods provided by Pearsall (2000) with modifications based on Rosen's (1989, pp 69-70) protocol. Specific details of the methods are described in full by Hart (2014, pp 93-97). Once extracted, $0.0010 \pm 0.0002 \mathrm{~g}$ was mounted in three drops of Canada balsam and covered with a coverslip to form a permanent mount. Each sample was scanned using a Zeiss Axiostar Plus at $400 \times$ magnification and $300-400$ single cell phytoliths and 50-100 multicell phytoliths were counted per slide according to Albert and Weiner's (2001) protocol. Phytoliths were identified through comparison with the University of Connecticut Archaeobotany Laboratory reference collection and established literature (Mulholland and Rapp 1992; Rosen 1992; Twiss et al. 1969). Raw phytolith counts were divided by sediment mass in order to calculate adjusted counts per gram of sediment.

Paired sediment and flotation samples from the $<1 \mathrm{~mm}$ fraction were examined for spherulites in this study. The $\mathrm{pH}$ of each sediment sample was recorded by thoroughly mixing $10 \mathrm{ml}$ of sediment with $20 \mathrm{ml}$ of deionized water within a small beaker. Samples sat for $30 \mathrm{~min}$ to reach equilibrium conditions before the $\mathrm{pH}$ was measured using an Oakton Waterproof pHTestr 30. A range of grain-mount/sediment smear, thin-section and chemical extraction methods have previously been used to observe spherulites in sediments (e.g. Canti 1997; Matthews 2010; Gur-Arieh et al. 2013, 2014; Portillo et al. 2014, 2017; Lancelotti and Madella 2012). Given that our goal is to assess the potential of using a simple method that can easily be applied by a wide range of specialists to either sediment or flotation samples, we decided to follow Canti's $(1997,1998)$ "sediment smear" approach as closely as possible. Roughly $1 \mathrm{~g}$ of each sample was placed in a clean petri dish and pulverized using a razor blade and the end of a metal scoop. The resultant powder was sieved using a $125 \mu \mathrm{m}$ sieve and approximately $0.0200 \mathrm{~g}$ of the sample was weighed using an analytical balance recording sample mass to four decimal places. Each sample was then mounted in a drop of Canada balsam on a glass slide, covered with a cover slip, and left for a few days to set (other mounting media exist, including Entellan). All materials used were cleaned between samples to minimize cross-contamination. Slides were examined at $400 \times$ under XPL using a Leica DM2700 metallurgical microscope and compared to reference slides of spherulites within cow, sheep and goat dung collected across southern Armenia. Spherulite abundance was estimated by counting all spherulites visible within a $10 \times 10$ reticle grid within 10 semi-randomized fields of view. Attempts were made to cover as much of the slide as possible. In instances where masses of spherulites were found, an attempt was made to count all of the spherulites visible, but in some instances this proved difficult. When clumps of non-spherulite material obscured much of the field of view, another point on the slide was selected. Raw spherulite counts were divided by sample mass to provide an adjusted count per gram of sediment or floated material. The mean number of spherulites per field of view was calculated from the adjusted number of spherulites per count, along with ubiquity (number of fields of view that contained spherulites, expressed as a percentage) in order to gauge the level of homogeneity of spherulites across the slide.

\section{Results}

All sediment samples were moderately alkaline with $\mathrm{pH}$ values ranging from 7.88 to 8.38 (with a mean of 8.13 and a standard deviation of 0.13 ), indicating consistently good preservation potential for any deposited spherulites (Electronic Supplementary Material). Spherulites were present in both sediment and flotation samples, indicating that dung had contributed to some of the samples (a detailed discussion of this is provided below). The raw and adjusted spherulite counts for all samples are listed in the ESM along with the mean number of spherulites per field of view and associated ubiquity data. The mass of seeds and wood recovered from the flotation samples within the $>1 \mathrm{~mm}$ fractions are also included alongside the adjusted count of phytoliths recovered per gram of sediment to provide general information on associated plant remains. Photographs of spherulites observed within a pair of sediment and flotation samples from a pit (5418/6426) within Operation 14 are presented in Fig. 4. Bar-charts illustrating the adjusted counts of spherulites/g of sample from the pyrotechnic features and the domestic structure are presented in Figs. 5 and 6 respectively. Details of macro-botanical taxa and phytolith types recovered from select sediment samples are provided in Tables 1 and 2 (further information on these studies is provided in Smith et al. 2015b and; Hart 2014 respectively).

In general, the number of spherulites per gram of sediment is greater than that for associated flotation samples, which is to be expected, owing to the potential for dissolution or loss of spherulites through the flotation process (Figs. 5, 6). Large numbers of spherulites $(>1,500 / \mathrm{g}$ of sediment) were found in one pyrotechnic feature and four pits. Within these five samples, the attrition of spherulites caused by flotation appears to be fairly consistent and an excellent 
Table 1 Relative abundance of macro-botanical remains and shell recovered from flotation samples containing more than $1,500 \mathrm{spherulites} / \mathrm{g}$ of sediment $(+=$ present,$++=$ many,+++ = abundant)

\begin{tabular}{|c|c|c|c|c|c|}
\hline ZD Operation: sample number & $8: 3837$ & $11: 6458$ & $11: 6463$ & 14: 6426 & 14: 7260 \\
\hline Density $(\mathrm{ml} / \mathrm{L})$ & 0.3 & 9.5 & 3.0 & 6.8 & 5.9 \\
\hline Sample mass (g) & 0.83 & 42.6 & 11.2 & 26.4 & 15.6 \\
\hline Mass of wood >1 mm (g) & 0.05 & 3.28 & 0.88 & 11.9 & 2.21 \\
\hline Mass of seeds $>1 \mathrm{~mm}(\mathrm{~g})$ & 0.5 & 13.6 & 3.0 & 7.4 & 2.8 \\
\hline Context type & Pyrotech. feature & Pit/ hearth & Pit & Pit & Pit \\
\hline Adjusted spherulites/g sediment & 24,960 & 1,863 & 2,067 & 9,212 & 3,704 \\
\hline Wood & + & ++ & ++ & +++ & +++ \\
\hline Hordeum sp. (2-row) & & + & & + & \\
\hline Triticum monococcum & & & & & + \\
\hline Triticum cf. durum/aestivum & & & & & + \\
\hline Triticum sp. & & + & + & + & + \\
\hline Cerealia indet. & & + & ++ & & + \\
\hline Triticum sp. glume bases & + & +++ & ++ & +++ & +++ \\
\hline Triticum sp. rachis frag. & & & & + & + \\
\hline Hordeum rachis frag. & & & & & + \\
\hline Aegilops sp. spikelet base & & & & + & \\
\hline Culm frag. with node $(>2 \mathrm{~mm})$ & & & + & & \\
\hline Awn frag. & & & + & & ++ \\
\hline Fabaceae (large) & & + & & & + \\
\hline Lens culinaris & & + & + & + & \\
\hline cf. Prosopis sp. & & + & & & \\
\hline Lathyrus spp. & & + & & & \\
\hline Vicia ervilia & & & & + & \\
\hline Silene-type & & + & + & + & + \\
\hline \multicolumn{6}{|l|}{ Centaurea spp. } \\
\hline MalvalAlthaea spp. & & + & & & \\
\hline Boraginaceae & + & + & + & + & + \\
\hline Astragalus sp. & & + & + & + & \\
\hline Trigonella $\mathrm{sp}$. & & & + & & \\
\hline Coronilla sp. & & & + & & \\
\hline Medicago sp. & & & & & + \\
\hline Melilotus sp. & & + & & & \\
\hline Poaceae & + & + & & ++ & + \\
\hline Bromus sp. & & + & & & \\
\hline Lolium sp. & & + & + & + & + \\
\hline Hordeum sp. (wild) & + & & & & + \\
\hline Phalaris sp. & & & & & + \\
\hline Culm frag. without node $(<2 \mathrm{~mm})$ & & + & & + & \\
\hline Culm frag. with node $(<2 \mathrm{~mm})$ & + & & & & + \\
\hline Bolboschoenus maritimus & & + & + & & \\
\hline Cyperaceae & & + & & & + \\
\hline Shell & + & + & & + & + \\
\hline
\end{tabular}

correlation exists between adjusted counts for paired sediment and flotation samples $\left(R^{2}=0.932, n=5\right.$, Fig. 7). When considering only samples that contain small amounts of spherulites $(<1,500 / \mathrm{g}$ of sediment), no such correlation exists $\left(R^{2}=0.298, n=26\right)$, as illustrated the by large cluster of points scattered toward the origin of Fig. 7.

\section{Discussion}

The results of this study highlight relative differences in spherulite abundances between samples from different archaeological contexts as well as differences between paired sediment and flotation samples. As with most archaeological endeavours, interpreting these differences and attempting 
Table 2 Contents of phytolith samples from both the pyrotechnic features and domestic areas

\begin{tabular}{|c|c|c|c|c|c|c|c|c|c|c|c|}
\hline ZD Operation: sample number & 8: 5401 & 8: 5403 & 8: 5404 & $8: 5405$ & $11: 5444$ & 11: 5421 & $11: 5428$ & 14: 5417 & 14: 5418 & $11: 5427$ & 11: 5443 \\
\hline Context type & $\begin{array}{l}\text { Pyrotech. } \\
\text { feature }\end{array}$ & $\begin{array}{l}\text { Pyrotech. } \\
\text { feature }\end{array}$ & $\begin{array}{l}\text { Pyrotech. } \\
\text { feature }\end{array}$ & $\begin{array}{l}\text { Pyrotech. } \\
\text { feature }\end{array}$ & Hearth & $\begin{array}{l}\text { Hearth/ } \\
\text { pit }\end{array}$ & Pitfill & Pitfill & Pitfill & Bin & Floor \\
\hline \multicolumn{12}{|l|}{ Grass inflorescence: } \\
\hline Aegilops & & & & & & & 28,977 & & & 459 & \\
\hline Awn & 1,918 & & 800 & 15,845 & & 958 & & & & & \\
\hline Barley husk & 1,199 & & & & & & & 1,111 & 25,711 & & \\
\hline cf. cereal husk & 1,199 & & & & & 5,748 & & & & & \\
\hline Long (dendritic) & 30,693 & 68,910 & 23,200 & 112,619 & 687 & & & & & & 6,333 \\
\hline LS echinate & 7,194 & 37,587 & 8,000 & 10,482 & & 958 & & & & & 305 \\
\hline LS sinuate & 11,990 & 28,190 & 4,400 & 23,584 & & 2,874 & & & & & \\
\hline Papillae & 7,673 & 14,356 & 6,400 & 42,902 & & 18,064 & 67,613 & 18,681 & 78,098 & 12,352 & 2,375 \\
\hline Wheat husk & 2,398 & & 400 & 5,241 & & & 115,907 & 3,332 & 64,278 & 459 & \\
\hline Wild grass husk & 11,990 & 28,190 & 3,600 & 36,686 & 1,400 & 55,559 & 550,560 & 76,642 & 745,622 & 37,163 & 16,496 \\
\hline Wild grass/T. aestivum husk & & & & & & & & & 102,844 & & \\
\hline \multicolumn{12}{|l|}{ Grass leaf: } \\
\hline Bilobes & 11,510 & 275,640 & 8,800 & 21,451 & 687 & 6,569 & 96,590 & 3,503 & 11,570 & 7,059 & 4,750 \\
\hline Bulliform & 15,347 & 5,743 & 7,200 & 53,628 & 687 & 21,348 & 48,295 & 7,006 & 26,034 & 19,411 & 3,167 \\
\hline Crenates & 4,796 & 5,743 & 4,000 & 48,265 & 3,436 & 11,495 & 57,954 & 8,173 & 26,033 & 12,352 & 15,833 \\
\hline Cross sc & 2,878 & 11,485 & 2,400 & 10,726 & & 8,211 & & & & & \\
\hline Leaf/stem bilobe & 19,183 & 328,889 & 1,200 & 5,241 & & & & 1,111 & 12,856 & & \\
\hline Leaf/stem saddle & 5,995 & & & 5,241 & & & & & & & \\
\hline Panicoid leaf & 10,791 & & 1,200 & & & & & & & & \\
\hline Polylobes & & & & & & 1,642 & & & & & \\
\hline Rondels & 35,489 & 94,751 & 35,200 & 337,856 & 9,621 & 98,529 & 627,832 & 63,047 & 118,593 & 111,171 & 32,458 \\
\hline Saddles & 4,796 & 43,069 & 8,800 & 150,158 & 687 & 29,559 & 48,295 & 3,503 & 20,248 & 10,588 & 15,041 \\
\hline \multicolumn{12}{|l|}{ Grass leaf/stem: } \\
\hline Long (smooth) & 40,285 & 192,374 & 40,800 & 386,121 & 2,6115 & 65,686 & 511,924 & 60,712 & 222,723 & 86,466 & 52,249 \\
\hline LS psilate & 22,780 & 366,476 & 9,200 & 81,234 & 1,400 & 17,243 & 106,248 & 17,772 & 115,700 & 4,588 & 3,055 \\
\hline Grass stem: culm & & & & 2,620 & & 958 & 48,295 & 3,332 & 102,844 & & \\
\hline Grass: long (echinate) & 70,019 & 183,760 & 64,000 & 241,326 & 21,992 & 185,562 & $1,062,484$ & 169,293 & 303,713 & 234,694 & 94,999 \\
\hline Grass: long (sinuate) & 6,714 & 22,970 & 2,400 & 42,902 & 2,062 & 4,926 & 19,318 & 3,503 & 17,355 & 5,294 & 2,375 \\
\hline Monocot leaf: hairs & 5,755 & 37,326 & 2,400 & 37,540 & 687 & 3,284 & 28,977 & & 5,785 & 1,765 & 1,583 \\
\hline Monocot: trichomes & 3,837 & 5,743 & 2,400 & 16,088 & 687 & 8,211 & & & 5,785 & 1,765 & 1,583 \\
\hline Monocot: leaf/stem & 11,990 & & 400 & & 560 & 11,495 & 57,954 & 4,443 & 64,278 & 459 & 1,833 \\
\hline Leaf: stem stomata & 7,194 & 65,778 & & 10,482 & & 958 & 9,659 & & & 459 & \\
\hline Leaf/stem: stomata & & 14,356 & & & & & & & & & \\
\hline $\begin{array}{l}\text { Cyperaceae inflorescence: } \\
\text { cylindric smooth LC }\end{array}$ & 2,878 & 2,871 & & & & 1,642 & & & & & 792 \\
\hline Poaceae: Phragmites culm & 2,398 & & & 2,620 & & & & 1,111 & 25,711 & & \\
\hline Poaceae: Phragmites stem & 1,199 & & 400 & & & & & & & & \\
\hline Cyperaceae: cones & 5,755 & 25,841 & 7,200 & 58,991 & & & & & & & \\
\hline Cyperaceae: B & 3,597 & 37,587 & 400 & & & 958 & 38,636 & & 12,856 & 459 & \\
\hline Cyperaceae: $\mathrm{C}$ & 9,592 & & 2,000 & 18,343 & & & & & & & \\
\hline Dicotyledon leaf: platelet & 13,428 & 34,455 & 5,600 & 16,088 & & & & & & & \\
\hline $\begin{array}{l}\text { Woody/herbaceous leaf: } \\
\text { dicot polyhedron }\end{array}$ & 2,398 & & & & & & 19,318 & 1,111 & & & \\
\hline $\begin{array}{l}\text { Woody/herb: } \\
\text { square cell leaf/stem }\end{array}$ & 1,199 & 18,794 & 400 & & & & & & & & \\
\hline Woody leaf: sclereid & & & & & & & 28,977 & 2,335 & 2,893 & 3,529 & \\
\hline Woody leaf/branch: tracheids & & 11,485 & & & & & 19,318 & 1,168 & 2,893 & & \\
\hline $\begin{array}{l}\text { Woody/herbaceous wood/bark: } \\
\text { blocks }\end{array}$ & 959 & & 800 & 5,363 & & 9,853 & 9,659 & & & 1,765 & \\
\hline Total count & 399,016 & $1,962,369$ & 254,000 & $1,799,643$ & 70,708 & 572,290 & $3,602,790$ & 450,889 & $2,114,423$ & 552,257 & 255,227 \\
\hline
\end{tabular}

Phytolith abundances are expressed as a percentage of the total sediment processed per sample (n/gm) 
to relate this information to human behaviour is far from straightforward! Dung may be deposited on archaeological sites in both a "raw" and burned form and spherulite abundance within samples can vary based on a variety of factors including (but not restricted to): (1) the $\mathrm{pH}$ of the pasture upon which herbivores grazed and the age/health status of the herbivore producing the dung, which collectively determine the initial abundance of spherulites within the dung; (2) the amount of dung contributing to the sample, with greater volumes or denser/longer-term concentrations of dung presumably resulting in elevated counts; (3) the extent to which spherulites form "background noise" in sediments at sites where dung fuel is routinely stored and burned and/ or where animals were regularly penned onsite; (4) the $\mathrm{pH}$ of the sediment within which the remains are deposited and the volume and $\mathrm{pH}$ of post-depositional water flowing through the site, which may enhance spherulite dissolution; (5) the extent to which spherulites are mobile within a sediment profile after being deposited; (6) the $\mathrm{pH}$ of water used to recover the remains through flotation and possibly the method of flotation; and (7) the extent of dung fragmentation and spherulite clumping within the sample that may differentially bias counts.

Despite these variables, previous geo-archaeological research indicates that it is reasonable to link large numbers of spherulites with the presence of archaeological dung. As stated earlier, the converse may not necessarily always be true, and absence of spherulites may not always indicate absence of dung. That being said, in areas where the $\mathrm{pH}$ of soil within pastures used by herders is favourable to spherulite production, and the health status of the animals results in production (which may not always be assumed), it is likely that the variables governing spherulite abundances are relatively consistent within a phase of any given site and that samples can reasonably be compared to one another in relative terms. Further experimental and ethno-archaeological research is needed to test whether this assertion holds true.

\section{Spherulites abundance in sediment and flotation samples}

When comparing spherulite abundance between paired sediment and flotation samples, greater concentrations were generally observed within sediments. This is to be expected since spherulites are likely to be lost or dissolved during the flotation process. The rate of loss was fairly consistent, however (Fig. 7); when spherulites are present in abundance within sediments suggesting that dung contributed to the sample composition, the same relative abundances hold true for associated flotation samples. This is encouraging, and suggests that in instances where dung contributed heavily to a sample, spherulites should still be observable within the $<1 \mathrm{~mm}$ fraction of flotation samples. Consequently, while sediment provides the most reliable medium for observing spherulite abundances, this research suggests that the method could be applied to archived flotation assemblages that do not have associated sediment samples. This assertion should be tested with paired flotation and sediment samples from other sites to see if this approach can be universally applied across Southwest Asia. Given that machine flotation can sometimes be more vigorous, and that Canti (1997) observed the dissolution of spherulites in distilled water that was continually stirred, it would be useful to compare spherulite abundances between sediment and machine floated material before this technique is applied to archived machine floated material.

In three instances here, more spherulites were recorded in the floated material than the associated sediment sample (5443/7886, 8581/6700, 5425/7403, ESM) which initially seems counterintuitive. In all cases, the samples contained relatively low adjusted spherulite counts $(<650 / \mathrm{g})$. It is likely that low counts with low ubiquity are more easily skewed, particularly given that isolated clumps of spherulites in floated material can easily elevate counts. In a future study, it might be useful to modify the methods used to quantify spherulite chunks.

Within the sediment from Tell Zeidan, we identified five samples with "abundant" spherulites that were noticeably elevated relative to other samples. One came from a pyrotechnic feature (Fig. 5: 5405) and the others were collected from pits (Fig. 6: 8595, 8586, 5418, 8551). In each case, the samples contained $>1,500$ spherulites per $g$ of sediment. At present, it is unclear whether a numerical association between 1,500 spherulites per gram of sediment and "abundance" is site-specific, or will hold true at other sites, but it does appear that relative abundances are meaningful. Many samples from Zeidan contained relatively "few" spherulites, with adjusted counts below 750 spherulites per gram of sediment (Fig. 6). Particularly low counts $(<200 /$ g) were recorded from the burial (8554/7425) and bin (5427/7422) samples, which is encouraging since low to no counts were expected (humans tends to produce few to any spherulites and animal dung is not generally associated with these contexts). It is possible that the small amounts observed here represent low-level "background" noise. Other samples (e.g., $8597 / 8953$ and 5419/6480) fell in an intermediate area of relative abundance between 750 and 1,500 per gram of sediment and are more difficult to interpret. Future ethnoarchaeological and experimental work examining cereal processing and dung fuel use within mudbrick households would be tremendously beneficial in aiding interpretations, as would additional work examining spherulite abundance at other sites. 


\section{Patterning in fuel and plant use across Tell Zeidan}

The presence of abundant spherulites concentrations in five of the samples from Zeidan indicates that dung contributed towards those samples. Dung spherulites are particularly abundant in one pyrotechnic feature (5405/3837, Fig. 5), strongly suggesting the use of dung as a fuel during the firing process. Sillar (2000) reports the widespread use of herbivore dung within open and enclosed kilns in many parts of the world owing to its steady burn and ability to help control the burn environment. Few spherulites were recovered from the three other pyrotechnic features, but they were fairly ubiquitous within the samples. Phytolith remains recovered from four of the pyrotechnic features were more consistent, indicating similar concentrations of Cyperaceae, grassy inflorescences and leaf/stem types (including those with lower concentrations of spherulites) (Table 2). Macrobotanical remains were not well preserved and few taxa were recovered, possibly owing to the high temperatures reached in the kilns. Recovered taxa do compare well with phytolith data, however, indicating the presence of large amounts of Triticum dicoccum (emmer) glume bases and culm fragments with a diameter of $<2 \mathrm{~mm}$, indicative of wild grasses (Table 1). It is unclear whether the glume bases were: (1) added to the kiln as part of a chaff temper to control the burning environment; (2) fed to animals as fodder; or (3) added to fuel cakes when they were manufactured. Using SEM imaging, Valamoti (2013) observed different surface textures on glume bases digested by goats compared with undigested ones, so it should be possible to distinguish between these two possibilities in the future. The presence of small amounts of wood within the macro-botanical remains in all pyrotechnic features, along with small amounts of woody block and tracheid phytolith types in some of the samples, suggests that a variety of fuels were used. Future observations of ash pseudomorphs and the dimensions of growth rings within the wood could help assess the relative importance of wood versus dung within the features (e.g.,
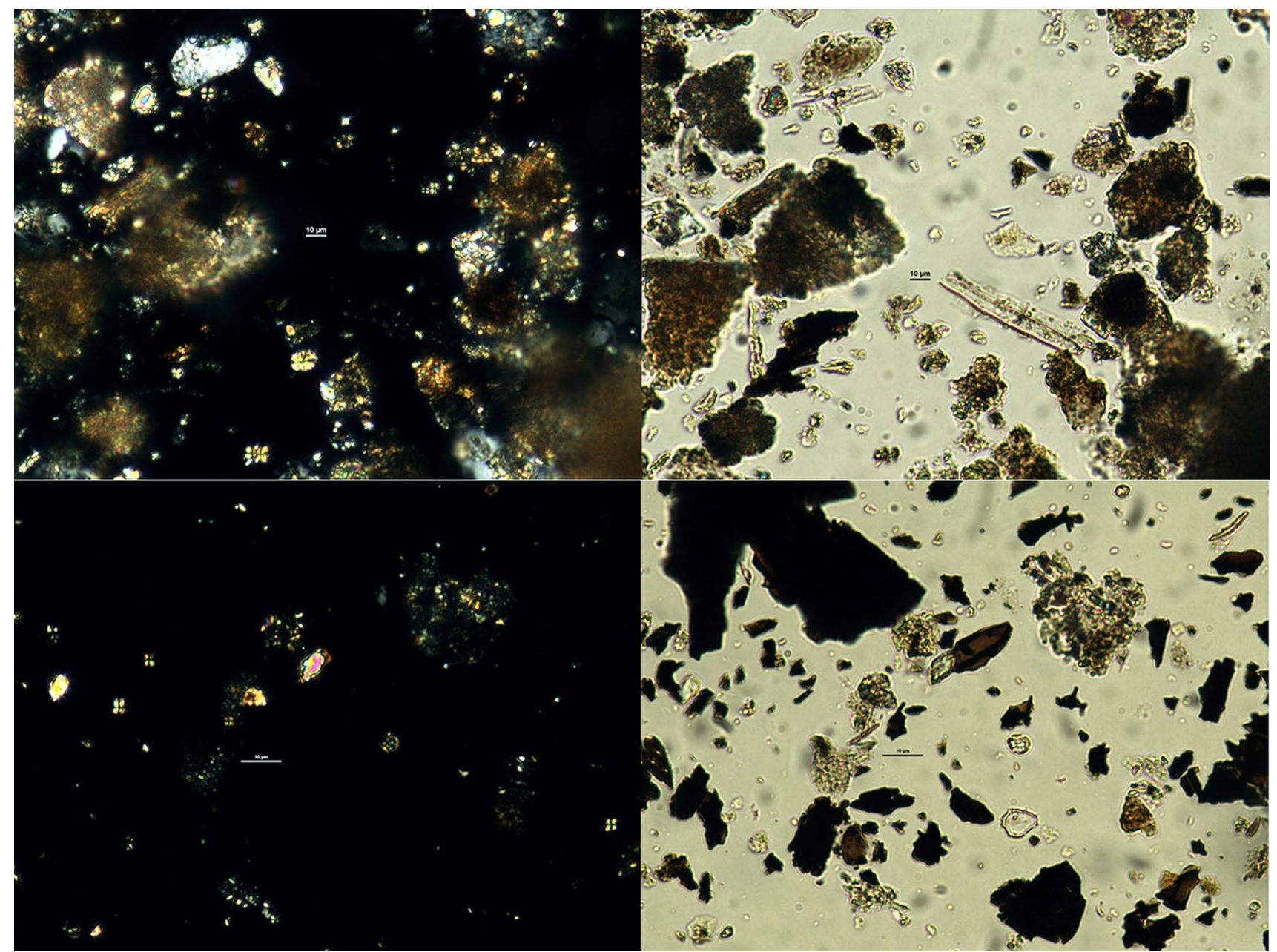

Fig. 4 Photograph of spherulites within sediment sample 5418 (top) and associated flotation sample 6426 (bottom) at $400 \times$ from a pit in Operation 14. The images to the left show cross-polarized light; the same view to the right displays the polarizer turned to 45 degrees (scale bars $=10 \mu \mathrm{m})$ 


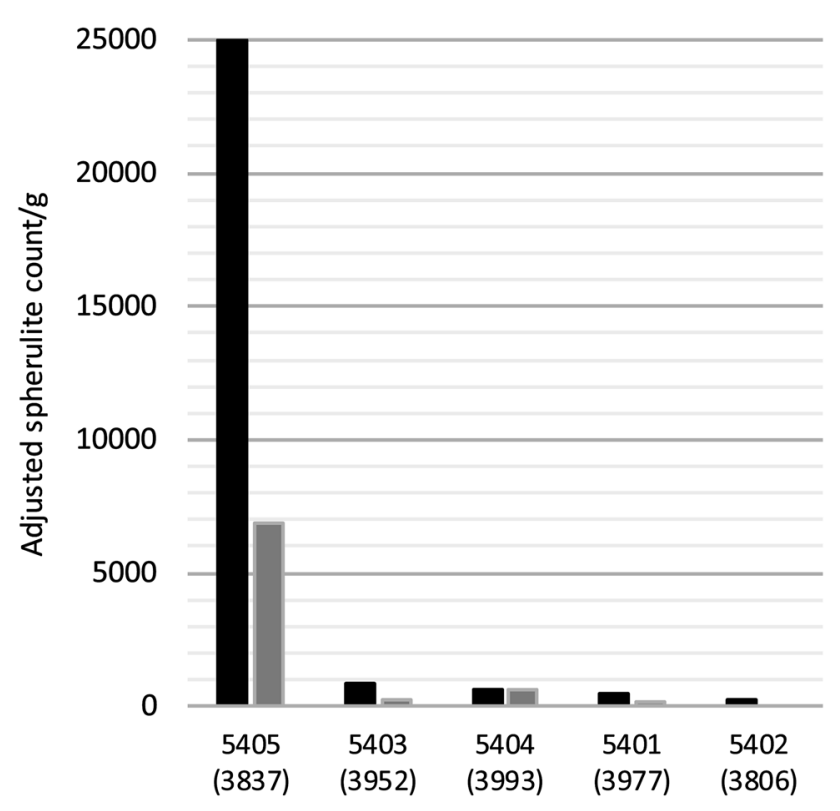

Fig. 5 Bar chart showing the adjusted number of spherulites/g for sediment (black) and flotation (grey) samples from Operation 8. All samples are from pyrotechnic features with the exception of the final control sample (5402[3806]) which was collected from a mudbrick wall used to construct the pyrotechnic features

Portillo et al. 2014; Gur-Arieh et al. 2014). The reason for the divergent spherulite counts between pyrotechnic features is unclear, but given that the features are likely to have been cleaned out regularly, the deposits may represent relatively short-term accumulations of fuel waste that are prone to greater variability than long-term accumulations resulting from regular and repeated activities.

Within the samples from the domestic structure spanning Operations 11 and 14, spherulites were found across the structure, but were most abundant in four of the pits and possibly the oven, indicating that dung fuel was used somewhere within the household (Fig. 6). Pits are often thought to represent long-term accumulations of repeated refuse disposal that could include a mixture of spent fuel, late-state crop processing waste, and miscellaneous household debris, thereby reflecting multiple activities. The four pit samples that were high in spherulites all yielded similar macrobotanical assemblages, further suggesting repeated patterns of behaviour (Table 2). These samples contained enormous amounts of emmer glume bases (on the order of 100s and in some instances 1,000 s) along with very few, poorly preserved Triticum and Hordeum cereal grains. In a previous study of the macro-botanical remains from Zeidan, Smith et al. (2015b) concluded that the large numbers of glume bases indicated waste from on-site processing of emmer spikelets for food. Phytoliths recovered from these pits demonstrate a focus on cereal husk types, further supporting the interpretation that crop processing contributed heavily to the assemblages in the domestic structure (Table 2). The spherulite data indicate that dung also contributed to the pits, so the glume bases in the domestic structure could represent late-stage crop processing waste that was either: (1) disposed of alongside other waste; (2) incorporated into dung cakes to be burned as a fuel; or (3) fed to animals as part of a fodder which then became incorporated into the dung. Based on ethnographic parallels, the latter two possibilities seem most likely; distinguishing between the three will be possible with future planned SEM work.

The abundance of wood in many of these pit samples (Table 1 and ESM) suggests that wood also served as an important fuel to the inhabitants of Zeidan and it is possible that wood and dung served different functions within ovens and hearths. The oven (5408/5820) sampled at Zeidan appears to have been fuelled with dung yet spherulites were noticeably scarce in the two hearths $(8579 / 7316,5444 / 7893)$ where macroscopic wood predominated (ESM; Fig. 6) indicative of wood fuel. Phytoliths recovered from hearth 5444 exhibited the lowest density and diversity of all samples, yet contained a relative dominance of woody blocks, further corroborating this interpretation (Table 2). Ethnographic observations in Armenia by Smith routinely documented storage of wood and dung fuels together in many rural households (Fig. 2), with dung being preferentially used for cooking within tannurs. This is not a new practice; referring to discussions within the Old Testament, Deckers (2011) describes three different oven types that were each associated with different fuels. In order to fully assess whether fuel selection routinely differed between ovens and hearths during the Ubaid period at Tell Zeidan or across Southwest Asia, more samples are needed. Future studies that attempt to explore the nuances of fuel selection within features and across sites would benefit by including observations of ash pseudomorphs. This research shows, however, that plant deposition across sites is complex and by using an integrated approach it is possible to distinguish between different depositional processes.

\section{Conclusions and future directions}

Flotation samples yield a wide variety of macro-botanical remains that hold enormous potential to provide rich interpretations regarding plant and/or fuel use in the past. The questions that can be asked of both macro- and microplant-based assemblages differ based on inferred processes of plant deposition. Researchers currently disagree on the extent to which dung fuel contributed to macro-botanical assemblages in antiquity. The inclusion of spherulite data generated through simple "sediment smears" is tremendously beneficial in isolating contexts that contain dung and can easily be applied in most archaeobotany labs with 
Fig. 6 Bar chart showing the adjusted number of spherulites/g for samples from a domestic structure spanning Operations 11 and 14 . Note that the burial sample 5411(5902) included as an additional control was excavated from Operation 9

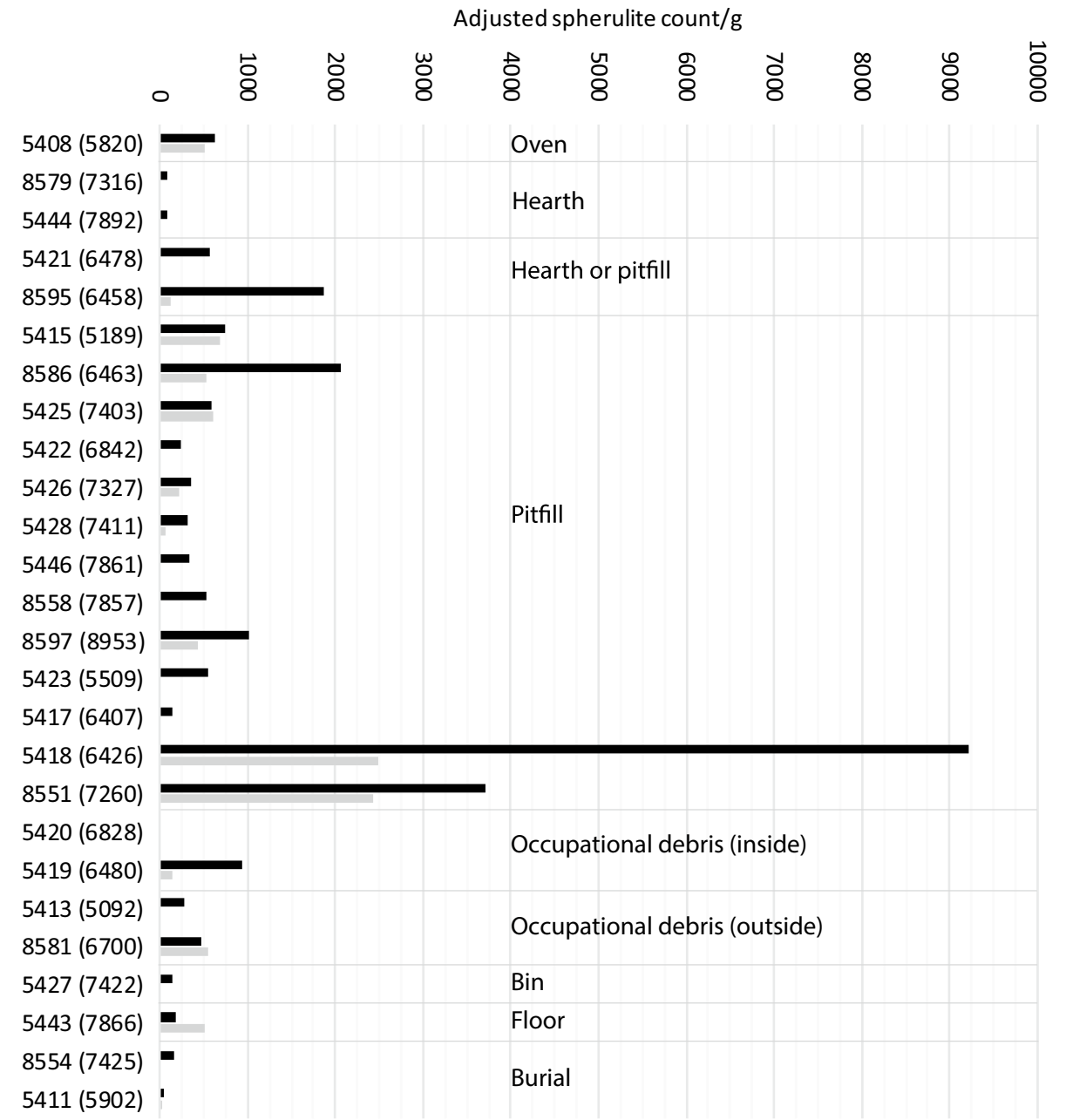

minimal effort. While sediment samples are methodologically preferable when attempting to assess relative spherulite abundance across a site, in instances where sediment is not available, archived flotation samples will still prove useful in isolating samples that contained large amounts of spherulites.

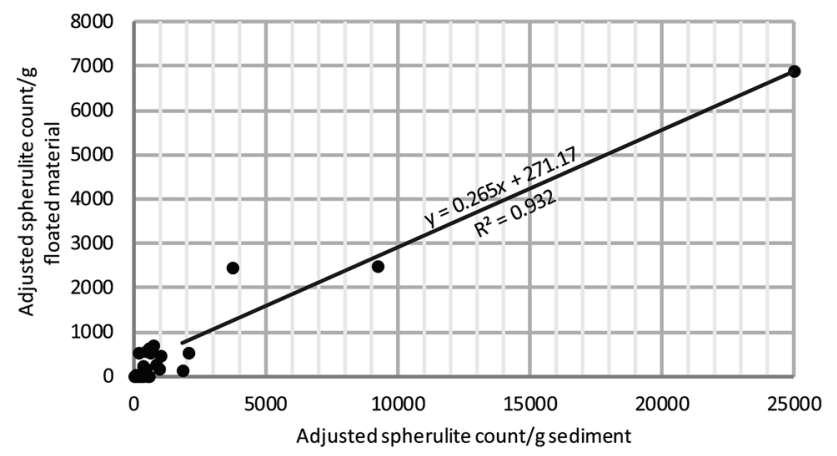

Fig. 7 Scatterplot of adjusted spherulite counts within paired sediment and flotation samples. Note that the correlation shows 5 samples with abundant spherulites. Correlation of all points: $R^{2}=0.932$; correlation of cluster of points with $<1,500$ spherulites/g sediments $R^{2}=0.298$
As with all archaeological methods, the approach presented in this study is not a panacea and a number of issues need to be carefully weighed. Spherulite production can vary based on the $\mathrm{pH}$ of soil within pasture lands, and preservation can be affected by sediment $\mathrm{pH}$ and the rate of water flowing through sediments. Understanding the potential for mixing and vertical movements of spherulites within sediments is important as we assess background noise and weigh meaningful differences in abundance. These differences could be explored through carefully designed experimental studies. Information gleaned from such studies would allow for a deeper consideration of whether spherulite counts have any meaning in absolute terms, whether they are best viewed in relative terms at the site/phase-level, and whether archaeologists should expect to see a certain minimum level of "background noise" at sites where dung fuel use or onsite animal penning was widespread. Both ethnographic and archaeological studies have demonstrated the strong predictive potential of spherulite to ash pseudomorphs ratios for distinguishing between remnants of predominantly wood and dung fuelled fires (e.g. Braadbaart et al. 2012; Gur-Arieh 
et al. 2014; Portillo et al. 2014, 2017), so incorporating these existing geo-archaeological approaches within future studies would also be beneficial.

Once dung fuel has been positively identified, it is possible to use botanical assemblages within dung-related samples to consider a broad range of social questions related to animal economies. First, it is clear from the findings presented here that dung was used as fuel during the Ubaid period within both domestic and craft specialization contexts and that this practice was established prior to widespread deforestation in the region. This indicates that a wide range of cultural choices informed fuel choice beyond the availability of wood fuels. It is unclear when the widespread use of dung as a fuel first began and intensified as part of the Secondary Products Revolution, but it was likely widespread across Southwest Asia during the Ubaid and Chalcolithic (Katz et al. 2007) and possibly earlier. Second, it is possible to consider what the range of plant remains within dung-related samples indicate about animal diet. It should be noted that while securely identified dung remains can provide insight into ancient foddering or pasturing practices, plants preserved within dung should not be viewed as simple reflections of animal diet owing to: (1) preservation biases exercised by the animal's digestive system; and (2) the ways in which dung cakes are manufactured. Small weed seeds with robust seed coats that can be dispersed via endozoochory (ingestion and excretion by animals) and thick glume bases tend to be preserved much better within the gut than cereal grains and more fragile chaff parts that may also have formed part of an animal's diet (Spengler 2018). Additionally, the degree to which cereals, in particular, are differentially digested can vary between wheat and barley and whether the grains are consumed by sheep/goats or cows (Wallace and Charles 2013; Valamoti and Charles 2005; Anderson and Ertug-Yaras 1998). Careful consideration of the taphonomy of fodder plants must therefore be included in any examination of dung-derived plant remains. Regarding the second point, building upon Valamoti's (2013) SEM study, future feeding experiments with sheep, goats and cows that incorporate a fuller range of plants typically recovered in macro-botanical samples would be tremendously valuable in assessing whether surface textural differences on undigested fragments could help tease apart plant remains that were consumed by an animal or added to dung cakes in instances where the presence of dung has been confirmed.

While the sample size examined here is small, we believe that our study is robust enough to demonstrate the enormous potential of integrating dung spherulite analysis with traditional archaeobotanical techniques to help better assess the origin and depositional histories of macro-botanical samples. Previous studies have also shown that, when available, phytolith data further enrich interpretations. By adopting a multi-proxy approach, insights into sample origin are honed, allowing for better substantiated interpretations. Our results highlight the need for future experimental and ethno-archaeological work to help deepen interpretations of integrated macro-botanical, micro-botanical and geo-archaeological data. Once charred dung is securely identified within macrobotanical samples using objective means, the rich potential of archaeobotanical analyses to address a wide range of socio-economic and environmental questions including choices regarding foddering, pasturing and fuel selection can be harnessed more fully.

Acknowledgements This paper is dedicated to Naomi Miller in honour of her seminal work on dung fuel use in Southwest Asia and to the memory of Gordon Hillman for his enormous contributions to the field. We are immensely grateful to Anas al-Khabour and Mohammed Sarhan of the Raqqa Museum, who co-directed the excavations of the Syrian-American Tell Zeidan project during the 2008 and 2009/2010 seasons respectively. Many thanks are owed to the Syrian Directorate General of Antiquities and Museums for their assistance in facilitating the export of the archaeobotanical and sediment samples. We thank Abu Turki for his help floating samples during the 2009 season. We also thank the entire Tell Zeidan team and in particular Michael Fisher and Kate Grossman for providing contextual information for the samples discussed here. We are grateful to Philip J. Graham and Cathleen Hammel for their help sorting the macro-botanical remains from Tell Zeidan and to Steven Zinn, Hilarie Jones, Nelli Hovhannisyan, Boris Gasparyan, Charles Turner, and Daniel Adler for their help securing modern comparative dung samples. Many thanks are owed to villagers of Yelpin in Armenia for allowing Alexia Smith into their home to examine a tannur and take photographs of fuel use and storage, and to Agriculture Specialist Patrick Mulé at US Customs and Border Protection for his help importing the dung samples. Funding for archaeobotanical and sediment sample collection was provided through a University of Connecticut Large Faculty grant and funding for analysis was provided through a National Science Foundation Early Faculty CAREER Award (No. 1136516), both granted to Alexia Smith. We thank Alan Farahani, John (Mac) Marston, and Chantel White for organizing the SAA session that this paper was first presented in; Daniel Adler for his useful comments on earlier drafts of the paper; two anonymous reviewers for their very helpful comments and suggestions on an earlier draft; and Paul Goldberg for sowing the seeds of this paper many years ago. Any oversights remain our own.

Open Access This article is distributed under the terms of the Creative Commons Attribution 4.0 International License (http://creativeco mmons.org/licenses/by/4.0/), which permits unrestricted use, distribution, and reproduction in any medium, provided you give appropriate credit to the original author(s) and the source, provide a link to the Creative Commons license, and indicate if changes were made.

\section{References}

Albert RM, Shahack-Gross R, Cabanes D, Gilboa A, Lev-Yadun S, Portillo M, Sharon I, Boaretto E, Weiner S (2008) Phytolith-rich layers from the Late Bronze and Iron Ages at Tel Dor (Israel): mode of formation and archaeological significance. J Archaeol Sci 35:57-75. https://doi.org/10.1016/j.jas.2007.02.015

Albert RM, Weiner S (2001) Study of phytoliths in prehistoric ash layers from Kebara and Tabun caves using a quantitative approach. In: Meunier JD, Colin F (eds) Phytoliths: applications 
in earth sciences and human history. Balkema Publishers, Lisse, pp 251-266

Anderson S, Ertug-Yaras F (1998) Fuel fodder and faeces: an ethnographic and botanical study of dung fuel use in central Anatolia. Environ Archaeol 1:99-109. https://doi.org/10.1179/ env.1996.1.1.99

Bates J, Singh RN, Petrie CA (2017) Exploring Indus crop processing: combining phytolith and macrobotanical analyses to consider the organisation of agriculture in northwest India c. 3200-1500 BC. Veget Hist Archaeobot 26:25-41. https://doi. org/10.1007/s00334-016-0576-9

Berna F (2017) Geo-ethnoarchaeology study of the traditional Tswana dung floor from the Moffat Mission Church, Kuruman, North Cape Province, South Africa. Archaeol Anthropol Sci 9:1,115-1,123. https://doi.org/10.1007/s12520-017-0470-0

Boardman S, Jones G (1990) Experiments on the effects of charring on cereal plant components. J Archaeol Sci 17:1-11

Bogaard A, Palmer C, Jones G, Charles M (1999) A FIBS approach to the use of weed ecology for the archaeobotanical recognition of crop rotation regimes. J Archaeol Sci 26:1,211-1,224

Bottema S (1984) The composition of modern charred seed assemblages. In: van Zeist W, Casparie WA (eds) Plants and ancient man. Studies in palaeoethnobotany. Balkema, Rotterdam, pp 207-212

Braadbaart F, Poole I, Huisman HDJ, van Os B (2012) Fuel, fire and heat: an experimental approach to highlight the potential of studying ash and char remains from archaeological contexts. J Archaeol Sci 39:836-847. https://doi.org/10.1016/j. jas.2011.10.009

Brochier JE (1983) Bergeries et feux de bois néolithiques dans le Midi de la France. Quartär 33/34:181-193

Brochier JE, Villa P, Giacomarra M, Tagliacozzo A (1992) Shepherds and sediments: geo-ethnoarchaeology of pastoral sites. J Anthropol Archaeol 11:47-102

Bull ID, Elhmmali MM, Perret V, Matthews W, Roberts DJ, Evershed RP (2005) Biomarker evidence of faecal deposition in archaeological sediments of Çatalhöyük. In: Hodder I (ed) Inhabiting Çatalhöyük: reports from the 1995-99 seasons. McDonald Institute for Archaeological Research, Cambridge, pp 415-420

Bull ID, Simpson IA, van Bergen PF, Evershed RP (1999) Muck 'n' molecules: organic geochemical methods for detecting ancient manuring. Antiquity 73:86-96

Canti MG (1997) An investigation of microscopic calcareous spherulites from herbivore dungs. J Archaeol Sci 24:219-231. https:// doi.org/10.1006/jasc. 1996.0105

Canti MG (1998) The micromorphological identification of faecal spherulites from archaeological and modern materials. J Archaeol Sci 25:435-444. https://doi.org/10.1006/ jasc. 1997.0210

Canti MG (1999) The production and preservation of faecal spherulites: animals, environment and taphonomy. J Archaeol Sci 26:251-258. https://doi.org/10.1006/jasc.1998.0322

Canti MG, Nicosia C (2018) Formation, morphology and interpretation of darkened faecal spherulites. J Archaeol Sci 89:32-45. https://doi.org/10.1016/j.jas.2017.11.004

Charles M (1998) Fodder from dung: the recognition and interpretation of dung-derived plant material from archaeological sites. Environ Archaeol 1:111-122. https://doi.org/10.1179/env.1996.1.1.111

Charles M, Bogaard A (2001) Third millennium BC charred plant remains from Tell Brak. In: Oates D, Oates J, McDonald H (eds) Excavations at Tell Brak vol 2: Nagar in the third millennium BC. McDonald Institute for Archaeological Research, Cambridge, pp 301-326

Charles M, Hald MM (2003) Crop production and use at Tell Brak in the fourth millennium BC. Iraq 65:26-32
Deckers K (2011) The "dung-as-fuel" model tested at two Syrian Jezirah sites. In: Deckers K (ed) Holocene landscapes through time in the Fertile Crescent. Brepols, Turnhout, pp 143-156

Elliott S, Bendrey R, Whitlam J, Aziz KR, Evans J (2015) Preliminary ethnoarchaeological research on modern animal husbandry in Bestansur, Iraqi Kurdistan: integrating animal, plant and environmental data. Environ Archaeol 20:283-303. https://doi. org/10.1179/1749631414Y.0000000025

Evershed RP, Bethell PH, Reynolds PJ, Walsh NJ (1997) $5 \beta$-stigmastanol and related $5 \beta$-stanols as biomarkers of manuring: analysis of modern experimental material and assessment of the archaeological potential. J Archaeol Sci 24:485-495. https:// doi.org/10.1006/jasc.1996.0132

Fall PL, Falconer SE, Klinge J (2015) Bronze age fuel use and its implications for agrarian landscapes in the eastern Mediterranean. J Archaeol Sci 4:182-191. https://doi.org/10.1016/j.jasre p.2015.09.004

Friesem DE (2016) Geo-ethnoarchaeology in action. J Archaeol Sci 70:145-157. https://doi.org/10.1016/j.jas.2016.05.004

Fuller DQ, Stevens C, McClatchie M (2014) Routine activities, tertiary refuse, and labor organization. Social inferences from everyday archaeobotany. In: Madella M, Lancelotti C, Savard M (eds) Ancient plants and people: contemporary trends in archaeobotany. The University of Arizona Press, Tucson, pp 174-217

Goren Y (1999) On determining use of pastoral cave sites: a critical assessment of spherulites in archaeology. J Israel Prehist Soc 29:123-128

Graham PJ, Smith A (2012) Integrating household archaeology and archaeobotany: a case study from Ubaid Kenan Tepe, Southeastern Anatolia. In: Parker BJ, Foster CP (eds) New perspectives on household archaeology. Eisenbrauns, Winona Lake, Indiana, pp 247-265

Graham PJ, Smith A (2013) A Day in the life of an Ubaid household: archaeobotanical investigations at Kenan Tepe, Southeastern Turkey. Antiquity 87:405-417

Gur-Arieh S, Mintz E, Boaretto E, Shahack-Gross R (2013) An Ethnoarchaeological study of cooking installations in rural Uzbekistan: development of a new method for identification of fuel sources. J Archaeol Sci 40:4,331-4,347. https://doi.org/10.1016/j. jas.2013.06.001

Gur-Arieh S, Shahack-Gross R, Maeir AM, Lehmann G, Hitchcock LA, Boaretto E (2014) The taphonomy and preservation of wood and dung ashes found in archaeological cooking installations: case studies from Iron Age Israel. J Archaeol Sci 46:50-67. https://doi. org/10.1016/j.jas.2014.03.011

Hart TC (2014) Phytoliths, starch grains, and emerging social complexity at Tell Zeidan, Syria. Doctoral Dissertation, Anthropology Department, University of Connecticut

Hastorf CA, Wright MF (1998) Interpreting wild seeds from archaeological sites: a dung charring experiment from the Andes. J Ethnobiol 18:211-227

Helbaek H (1969) Plant collecting, dry-farming, and irrigation in prehistoric Deh Luran. In: Hole F, Flannery KV, Neely JA (eds) Prehistory and human ecology of the Deh Luran Plain: An early village sequence from Khuzistan, Iran. University of Michigan Museum of Anthropology, Ann Arbor, pp 383-426

Hillman GC (1975) Appendix A. The plant remains from Tell Abu Hureyra: a preliminary report. Proc Prehist Soc 41:70-73

Hillman G (1981) Reconstructing crop husbandry practices from charred remains of crops. In: Mercer R (ed) Farming practice in British prehistory. University Press, Edinburgh, pp 123-162

Hillman G (1984) Traditional husbandry and processing of archaic cereals in recent times: the operations, products, and equipment which might feature in Sumerian texts. Bull Sumerian Agric $1: 114-152$ 
Hillman GC, Colledge SM, Harris DR (1989) Plant-food economy during the Epipaleolithic period at Tell Abu Hureyra, Syria: Dietary diversity, seasonality, and modes of exploitation. In: Harris DR, Hillman GC (eds) Foraging and farming: the evolution of plant exploitation. Unwin Hyman, London, pp 240-268

Hillman GC, Legge AJ, Rowley-Conwy PA (1997) On the Charred Seeds from Epipalaeolithic Abu Hureyra: Food or Fuel? Curr Anthropol 38:651-655. https://doi.org/10.1086/204651

Jarman HN, Legge AJ, Charles JA (1972) Retrieval of plant remains from archaeological sites by froth flotation. In: Higgs ES (ed) Papers in Economic Prehistory: studies by members and associates of the British Academy major research project in the early history of agriculture. University Press, Cambridge, pp 39-48

Jones AKG, Hutchinson AR, Nicholson C (2015) The worms of Roman horses and other finds of intestinal parasite eggs from unpromising deposits. Antiquity 62:275-276. https://doi.org/10.1017/S0003 598X00074007

Jones GEM (1984) Interpretation of archaeological plant remains: ethnographic models from Greece. In: van Zeist W, Casparie WA (eds) Plants and ancient man: studies in palaeoethnobotany. Balkema, Rotterdam, pp 43-61

Jones G, Charles M, Bogaard A, Hodgson J (2010) Crops and weeds: the role of weed functional ecology in the identification of crop husbandry methods. J Archaeol Sci 37:70-77

Katz O, Gilead I, Bar P, Shahack-Gross R (2007) Chalcolithic agricultural life at Grar, Northern Negev, Israel: dry farmed cereals and dung-fueled hearths. Paléorient 33:101-116

Lancelotti C, Madella M (2012) The 'invisible' product: developing markers for identifying dung in archaeological contexts. J Archaeol Sci 39:953-963. https://doi.org/10.1016/j. jas.2011.11.007

Lancelotti C, Ruiz-Pérez J, García-Granero JJ (2017) Investigating fuel and fireplaces with a combination of phytoliths and multi-element analysis; an ethnographic experiment. Veget Hist Archaeobot 26:75-83. https://doi.org/10.1007/s00334-016-0574-y

Madella M (2003) Investigating agriculture and environment in South Asia: present and future conbributions from opal phytoliths. In: Weber SA, Belcher WR (eds) Indus ethnobiology: new perspectives from the field. Lexington Books, Oxford, pp 199-249

Marinova E, Linseele V, Kühn M (2013) Bioarchaeological research on animal dung-possibilities and limitations. Environ Archaeol 18:1-3. https://doi.org/10.1179/1461410313Z.00000000023

Matthews W (2010) Geoarchaeology and taphonomy of plant remains and microarchaeological residues in early urban environments in the Ancient Near East. Quat Int 214:98-113. https://doi. org/10.1016/j.quaint.2009.10.019

McCorriston J, Weisberg S (2002) Spatial and temporal variation in Mesopotamian agricultural practices in the Khabur Basin, Syrian Jazira. J Archaeol Sci 29:485-498. https://doi.org/10.1006/ jasc. 2001.0741

Miller NF (1982) Economy and environment of Malyan, a third millennium B.C. urban center in southern Iran. Doctoral Dissertation, Department of Anthropology, University of Michigan, Ann Arbor

Miller NF (1984a) The interpretation of some carbonized cereal remains as remnants of dung cake fuel. Bull Sumerian Agric $1: 45-47$

Miller NF (1984b) The use of dung as fuel: an ethnographic example and an archaeological application. Paléorient 10:71-79

Miller NF (1985) Paleoethnobotanical evidence for deforestation in Ancient Iran: a case study of urban Malyan. J Ethnobiol 5:1-19

Miller NF (1990) Clearing land for farmland and fuel: archaeobotanical studies of the ancient Near East. In: Miller NF (ed) Economy and Settlement in the Near East: analyses of ancient sites and materials. MASCA, The University Museum of Archaeology and Anthropology, University of Pennsylvania, Philadelphia, pp 70-78
Miller NF (1991) The Near East. In: van Zeist W, Wasylikowa K, Behre K-E (eds) Progress in Old World palaeoethnobotany: a retrospective view on the occasion of 20 years of the international work group for palaeoethnobotany. Balkema, Rotterdam, pp 133-160

Miller NF (1996) Seed eaters of the ancient Near East: human or herbivore? Curr Anthropol 37:521-528

Miller NF (1997a) Farming and herding along the Euphrates: environmental constraint and cultural choice (fourth to second millennia B.C.). In: Zettler R (ed) Subsistence and settlement in a marginal environment: Tell es-Sweyhat, 1989-1995 preliminary report. MASCA, University of Pennsylvania, Philadelphia, pp 123-181

Miller NF (1997b) Reply to "On the Charred Seeds from Epipalaeolithic Abu Hureyra: Food or Fuel"? by Hillman GC, Legge AJ, Rowley-Conwy PA. Curr Anthropol 38:655-659. https://doi. org/10.1086/204651

Miller NF (2010) Botanical aspects of environment and economy at Gordion, Turkey. University of Pennsylvania Press, Philadelphia

Miller NF, Gleason KL (1994) Fertilizer in the identification and analysis of cultivated soil. In: Miller NF, Gleason KL (eds) The archaeology of garden and field. University of Pennsylvania Press, Philadelphia, pp 25-43

Miller NF, Marston JM (2012) Archaeological fuel remains as indicators of ancient west Asia agropastoral and land-use systems. J Arid Environ 86:97-103. https://doi.org/10.1016/j.jarid env.2011.11.021

Miller NF, Smart TL (1984) Intentional burning of dung as fuel: a mechanism for the incorporation of charred seeds into the archeological record. J Ethnobiol 4:15-28

Miller NF, Zeder MA, Arter SR (2009) From food and fuel to farms and flocks: the integration of plant and animal remains in the study of the agropastoral economy at Gordion, Turkey. Curr Anthropol 50:915-924. https://doi.org/10.1086/606035

Morse HW, Donnay JDH (1932) Spherulite optics. Am J Sci 5:440461. https://doi.org/10.2475/ajs.s5-23.137.440

Morse HW, Donnay JDH (1936) Optics and structure of three-dimensional spherulites. Am Mineral 21:391-439

Mulholland SC, Rapp G Jr (1992) A morphological classification of grass silica-bodies. In: Mulholland SC, Rapp G Jr (eds) Phytolith systematics: emerging issues. Plenum Press, New York, pp 65-89

Panadès i Blas X, Bartolomé i Filella J, Strömberg C, Soriano i Tomàs I, Buckland P, Serieyssol KK, Bach i Plaza J, Arillo Aranda A, Lozar F, Stevenson T, Chamorro i Lorenzo L, Ditchfield P (2017) The utility of livestock dung for reconstructing recent ethnological and environmental histories. Environ Archaeol 22:128-146. https ://doi.org/10.1080/14614103.2016.1142630

Pearsall DM (2000) Paleoethnobotany: a handbook of procedures. Academic Press, London

Picornell Gelabert L, Asouti E, Martí EA (2011) The ethnoarchaeology of firewood management in the Fang villages of Equatorial Guinea, central Africa: implications for the interpretation of wood fuel remains from archaeological sites. J Anthropol Archaeol 30:375-384. https://doi.org/10.1016/j.jaa.2011.05.002

Portillo M, Belarte MC, Ramon J, Kallala N, Sanmartí J, Albert RM (2017) An ethnoarchaeological study of livestock dung fuels from cooking installations in northern Tunisia. Quat Int 431:131-144. https://doi.org/10.1016/j.quaint.2015.12.040

Portillo M, Kadowaki S, Nishiaki Y, Albert RM (2014) Early Neolithic household behavior at Tell Seker al-Aheimar (Upper Khabur, Syria): a comparison to ethnoarchaeological study of phytoliths and dung spherulites. J Archaeol Sci 42:107-118. https://doi. org/10.1016/j.jas.2013.10.038

Reddy SN (1998) Fueling the hearths in India: the role of dung in paleoethnobotanical interpretation. Paléorient 24:61-70

Riehl S (1999) Bronze Age environment and economy in the Troad. the archaeobotany of Kumtepe and Troy. Mo Vince Verlag, Tübingen 
Riehl S (2009) Archaeobotanical evidence for the interrelationship of agricultural decision-making and climate change in the ancient Near East. Quat Int 197:93-114

Rosen AM (1989) Microbotanical evidence for cereals in Neolithic levels at Tel Teo and Yiftahel in the Galilee, Israel. J Israel Prehist Soc 22:68-77

Rosen AM (1992) Preliminary identification of silica skeletons from Near Eastern archaeological sites: an anatomical approach. In: Mulholland SC, Rapp G Jr (eds) Phytolith systematics: emerging issues. Plenum Press, New York, pp 129-147

Schelvis J (1992) The identification of archaeological dung deposits on the basis of remains of predatory mites (Acari; Gamasida). J Archaeol Sci 19:677-682. https://doi.org/10.1016/03054403(92)90037-4

Schepers M, van Haaster H (2015) Dung matters: an experimental study into the effectiveness of using dung from hay-fed livestock to reconstruct local vegetation. Environ Archaeol 20:66-81. https ://doi.org/10.1179/1749631414Y.0000000030

Shahack-Gross R (2011) Herbivorous livestock dung: formation, taphonomy, methods for identification, and archaeological significance. J Archaeol Sci 38:205-218. https://doi.org/10.1016/j. jas.2010.09.019

Shillito L-M, Matthews W (2013) Geoarchaeological Investigations of Midden-Formation Processes in the Early to Late Ceramic Neolithic Levels at Çatalhöyük, Turkey ca. 8,550-8,370 cal вр. Geoarchaeology 28:25-49. https://doi.org/10.1002/gea.21427

Sillar B (2000) Dung by preference: the choice of fuel as an example of how Andean pottery production is embedded within wider technical, social and economic practices. Archaeometry 42:43-60. https ://doi.org/10.1111/j.1475-4754.2000.tb00865.x

Simpson IA, Dockrill SJ, Bull ID, Evershed RP (1998) Early anthropogenic soil formation at Tofts Ness, Sanday, Orkney. J Archaeol Sci 25:729-746. https://doi.org/10.1006/jasc.1997.0216

Smith A (2012) Akkadian and post-Akkadian Plant Use at Tell Leilan. In: Weiss H (ed) Seven generations since the fall of Akkad. Studia Chaburensia 3. Harrassowitz, Wiesbaden, pp 225-240

Smith A, Dotzel K, Fountain J, Proctor L, von Baeyer M (2015a) Examining fuel use in antiquity: archaeobotanical and anthracological approaches in southwest Asia. Ethnobiol Lett 6:192-195

Smith A, Graham PJ, Stein GJ (2015b) Ubaid plant use at Tell Zeidan. Syria Paléorient 41:51-69
Spengler RN (2018) Dung burning in the archaeobotanical record of West Asia: where are we now? Veget Hist Archaeobot. https://doi. org/10.1007/s00334-018-0669-8

Stein GJ (2009) Tell Zeidan. In: Oriental Institute Annual Report 2008-2009. Oriental Institute, University of Chicago, Chicago, pp 122-139

Stein GJ (2010) Tell Zeidan. In: Oriental Institute Annual Report 2009-2010. Oriental Institute, University of Chicago, Chicago, pp 105-118

Stein GJ (2011) Tell Zeidan. In: Oriental Institute Annual Report 2010-2011. Oriental Institute, University of Chicago, Chicago, pp 121-138

Stevens CJ (2003) An investigation of agricultural consumption and production models for prehistoric and Roman Britain. Environ Archaeol 8:61-76

Théry-Parisot I, Chabal L, Chrzavzez J (2010) Anthracology and taphonomy, from wood gathering to charcoal analysis. A review of the taphonomic processes modifying charcoal assemblages, in archaeological contexts. Palaeogeogr Palaeoclimatol Palaeoecol 291:142-153. https://doi.org/10.1016/j.palaeo.2009.09.016

Twiss PC, Suess E, Smith RM (1969) Morphological classification of grass phytoliths. Soil Sci Soc Am Proc 33:109-115

Valamoti SM (2007) Detecting seasonal movement from animal dung: an investigation in Neolithic northern Greece. Antiquity 81:1,053-1,064. https://doi.org/10.1017/S0003598X00096113

Valamoti SM (2013) Towards a distinction between digested and undigested glume bases in the archaeobotanical record from Neolithic northern Greece: a preliminary experimental investigation. Environ Archaeol 18:31-42. https://doi.org/10.1179/1461410313 Z.00000000021

Valamoti SM, Charles M (2005) Distinguishing food from fodder through the study of charred plant remains: an experimental approach to dung-derived chaff. Veget Hist Archaeobot 14:528533. https://doi.org/10.1007/s00334-005-0090-y

Wallace M, Charles M (2013) What goes in does not always come out: the impact of the ruminant digestive system of sheep on plant material, and its importance for the interpretation of dung-derived archaeobotanical assemblages. Environ Archaeol 18:18-30. https ://doi.org/10.1179/1461410313Z.00000000022 